\title{
Indigenous Water, Sanitation and Hygienic (WaSH) Practices: The Case of the IP Community in Barangay Lower Panaga, Panabo, Philippines
}

\author{
Sabar G. Hasan, Jevannel G. Borlio, Junard P. Duterte \\ Davao del Norte State College, Philippines
}

\begin{abstract}
Every Filipino has a right to good health, especially those individuals who belong to marginalized sectors. This study explores the health realities of the members of Indigenous People (IP) community in Panabo City, with the hope to promote Basic Health Science Education (HSE) to these indigenous peoples. Utilizing an adapted and modified Water, Sanitation, and Hygiene (WASH) questionnaire, it was revealed that the way of life of the IPs in Barangay Lower Panaga had been influenced by the non-IP population they live with. It is evident that they already have improved knowledge, attitude and practices in the way they manage water, sanitation, solid waste, and hygiene promotion. However, it also emerged from the results the lack of knowledge of these IP members on the government programs they can avail, especially on health care services. Apparently, there are still indigenous practices they employ in their daily lives, which usually lead to poor health outcomes compared to their non-IP counterparts. Like any other IP communities, financial unstableness remains evident in this area. Hence, this study documented the realities of life of the indigenous peoples to stimulate the attention of the local leaders, especially those in the academe to pass over pedagogical efforts in helping this marginalized sector. It is hoped and expected that education can bring light to one of the identified Geographically Isolated and Disadvantaged Areas (GIDAs) in Davao del Norte.
\end{abstract}

Keywords: Indigenous Health Practices, Science and Health Education, WaSH Practices

\section{INTRODUCTION}

A $\mathrm{n}$ unfortunate reality, which is very common across the word's indigenous peoples, is the congenital inequality in terms of health status compared to the non-indigenous populations. At a closer examination, literatures claim that these people have different orientation about health status and health service needs. They have their own indigenous concepts of health and illness, which is different from those of the general scientific knowledge (Sarfati et al., 2018).

Globally, indigenous peoples suffer from poorer health and are more likely to experience disability, and reduced quality of life. Indigenous women experience health problems with particular severity, as they are disproportionately affected by natural disasters and armed conflicts, and are often denied access to education, land property, and other economic resources. Indigenous youth and adolescents face particular challenges in the realization of their right to health that are often not adequately addressed, including sexual and reproductive health and rights, and mental health (Smith, 2013).

Furthermore, in digging into the situation of the right to health of indigenous peoples in Asia, the United Nations Declaration on the Rights of Indigenous Peoples (UNDRIP) provides that, among others, indigenous peoples have the right, without any discrimination, to the improvement of their economic and social condition, including sanitation and health. As suggested, statistical and health data collection is a key challenge in addressing Indigenous health disparities across the world and within regions (Smylie \& Firestone, 2016).

Specifically, in the Philippine setting, it was described that one of the many challenges faced by indigenous peoples is disparities in health situation. Data indicates that circumstances of extreme poverty are significantly more prevalent among indigenous peoples than non-indigenous groups, and are rooted in other factors, such as a lack of access to education and social services. It should be noted that literatures support for the association between education and health is strong (Hibbard \& Greene, 2013; Smith, 2013).

\section{Objectives of the Study}

This exploratory inquiry was conducted to assess the needs of the IP community in relation to Health Science Education (HSE). Specifically, this study aimed to answer the following questions:

1. What is the demographic profile of the IP Community in Barangay Lower Panaga, Panabo City in terms of:
1.a Gender;
1.b Educational attainment;
1.c Ethnicity.

2. What are the realities of the IP Community in relation to HSE, in terms of:

2.1 health conditions;

2.2 water safety practices;

2.3 sanitation facilities;

2.4 recycling and solid waste management;

2.5 hygienic practices. 
3. What are the coping mechanisms of the IP Community and possible intervention activities of the stakeholders in order to deliver HSE to the community?

\section{METHODOLOGY}

In the conduct of this research, an adapted Water, Sanitation, and Hygiene (WaSH) questionnaire was utilized. For the research participants to understand the written questions, the researchers orally translated the questions in Bisaya dialect, which is the common language used in the community. Answers were recorded and manually noted by the researchers on the survey questionnaire sheets. In the hope of unraveling the realities of the lives of the IP members, on their knowledge, attitudes and practices on Health Science Education, a cluster of three (3) focus group discussions (FGD) was employed, to give a total of thirty-seven (37) participants.

To exercise ethical procedures in gathering their statements as the primary data, an informed consent form was issued and signed by the invited informants to signify their permission. Descriptive statistical treatment was utilized in analyzing the collected quantitative data and thematic analysis was done to analyze the gathered statements, giving rise to core ideas, which led to the generation of the essential themes.

\section{RESULTS AND DISCUSSION}

There were 37 IP members, including the three IP leaders who joined the survey. Table 1 shows the demographic profile of the research respondents. Based on the results, female participants dominate the group, which was very helpful because there were questions in the questionnaire, which concerned feminine hygienic practices. Moreover, there were seven (7) tribes represented in this group of the convened indigenous peoples. On the educational level attained by these IP members, almost half of them were on their secondary level and some just finished that level. Of the $48.6 \%$, there were only 5 who are still studying at the time this research was carried out.

Moreover, the research participants were asked to answer the adapted and modified WASH? questionnaire and the summary of their answers are presented in Table 2. It is evident in their health complaints that they are experiencing minor ailments, though the possibilities cannot be discarded that these aches they are complaining can also be symptoms of some serious diseases. During the interview, there were no mention of any general checkup that they get from government programs, even if they are entitled to do so. Instead, they emphasized that as long as the body pains are tolerable and that they can still endure it, they will just use the available herbal resources, bear the pain and hope for natural healing. This phenomenon was also described by Ghebreyesus (2018), when he said that since most indigenous peoples belong to the marginal sector in the community, they have hesitations in availing medical services, especially offered by private medical centers and hospitals, even public ones because they are afraid that the services they will offer, would be asking for monetary payment, which they cannot provide.

Table 1. Demographic Profile

\begin{tabular}{|c|c|c|c|}
\hline $\begin{array}{l}\text { Characteristic } \\
(\mathrm{n}=37)\end{array}$ & Level & No. & $\%$ \\
\hline \multirow[t]{2}{*}{ Gender } & Male & 12 & 32.4 \\
\hline & Female & 25 & 67.6 \\
\hline \multirow[t]{7}{*}{ Ethnicity } & Ata Manobo & 20 & 54.1 \\
\hline & Mandaya & 5 & 13.5 \\
\hline & Kagan & 1 & 2.7 \\
\hline & Suban-on & 2 & 5.4 \\
\hline & Sama & 1 & 2.7 \\
\hline & Manobo & 7 & 18.9 \\
\hline & B'laan & 1 & 2.7 \\
\hline \multirow[t]{6}{*}{$\begin{array}{l}\text { Educational } \\
\text { Attainment }\end{array}$} & None & 7 & 18.9 \\
\hline & Elementary Level & 6 & 16.2 \\
\hline & Elementary Graduate & 1 & 2.7 \\
\hline & Secondary Level & 18 & 48.6 \\
\hline & Secondary Graduate & 4 & 10.8 \\
\hline & Tertiary Level & 1 & 2.7 \\
\hline
\end{tabular}

In generating the essential themes, results revealed that each statement gathered corresponds to the indicators of the adapted questionnaire presented below and supported by authorities.

On Water Safety Practices, since most of these IP members are using mainly what is available in the community, they have encountered problems in accessing clean water because of lack of knowledge on the methods of water safety. Accordingly, they manually get the dirt visible to their naked eyes and once no residue is spotted, they would assume that it is already clean. Bradford et al (2016) put forth that with this unsanitary practice of the indigenous communities on water safety, it places the IPs at a very high risk of acquiring waterborne diseases.

On Sanitation Facilities, the low to no maintenance of the indigenous peoples in the materials they use every day may also put them into the brink of acquiring unwanted ailments. On the other hand, the only noticeable improvement in this aspect is the presence of private toilets for everyone, though not yet attached to their houses, also with no direct access to clean water because of the considerably far distance from the water source. 
Table 2. Realities of Health Science Education Status of IP Members

\begin{tabular}{|c|c|c|}
\hline Context & Label & Collected Incidents \\
\hline $\begin{array}{l}\text { Health } \\
\text { Conditions }\end{array}$ & $\begin{array}{l}\text { Health } \\
\text { Complaints }\end{array}$ & $\begin{array}{l}\text { body ache, stomachache, } \\
\text { backache, toothache, UTI, } \\
\text { difficulty in breathing, arthritis, } \\
\text { abdominal pain, muscle pain, } \\
\text { allergies from foods, diarrhea }\end{array}$ \\
\hline \multirow[t]{5}{*}{$\begin{array}{l}\text { Water Safety } \\
\text { Practices }\end{array}$} & Sources & $\begin{array}{l}\text { deep well, flowing water from the } \\
\text { nearby river, water pump device, } \\
\text { tap water }\end{array}$ \\
\hline & Inspection & local monthly inspection \\
\hline & $\begin{array}{l}\text { Cleaning } \\
\text { Schedule } \\
\end{array}$ & $\begin{array}{l}\text { every day, every after } 3 \text { days, } \\
\text { twice a week, once a month }\end{array}$ \\
\hline & Storage & Water jug \\
\hline & $\begin{array}{l}\text { Problems } \\
\text { Encountered }\end{array}$ & $\begin{array}{l}\text { inaccessibility to clean water, } \\
\text { deep well water with sand } \\
\text { residues }\end{array}$ \\
\hline \multirow[t]{3}{*}{$\begin{array}{l}\text { Sanitation } \\
\text { Facilities } \\
\end{array}$} & Private Toilet & All haveprivate toilets. \\
\hline & $\begin{array}{l}\text { Identified } \\
\text { Problems }\end{array}$ & $\begin{array}{l}\text { Inaccessibility to clean water for } \\
\text { kitchen, bathroom and toilet use. }\end{array}$ \\
\hline & $\begin{array}{l}\text { Ways on } \\
\text { preventing } \\
\text { Insects/rats/flies }\end{array}$ & $\begin{array}{l}\text { sanitize the surrounding with } \\
\text { bleaching powder and bar soap, } \\
\text { use of insecticides }\end{array}$ \\
\hline \multirow[t]{2}{*}{$\begin{array}{l}\text { Recycling and } \\
\text { Solid Waste } \\
\text { Management } \\
\end{array}$} & $\begin{array}{l}\text { Process of } \\
\text { disposal }\end{array}$ & $\begin{array}{l}\text { Burning of garbage, dumping of } \\
\text { garbage to a compost pit, feed to } \\
\text { animals }\end{array}$ \\
\hline & $\begin{array}{l}\text { Knowledge on } \\
\text { Recycling }\end{array}$ & Low to none \\
\hline \multirow[t]{11}{*}{$\begin{array}{l}\text { Hygienic } \\
\text { Practices }\end{array}$} & Buying Foods & $\begin{array}{l}\text { Observe vendor's appearance, } \\
\text { reheat before eating, cook their } \\
\text { own food }\end{array}$ \\
\hline & $\begin{array}{l}\text { Dealing with } \\
\text { Diarrhea Cases }\end{array}$ & $\begin{array}{l}\text { Boiling of guava or mahogany } \\
\text { leaves, over the counter medicines } \\
\text { and visit the barangay health } \\
\text { center }\end{array}$ \\
\hline & $\begin{array}{l}\text { Feminine } \\
\text { Hygienic } \\
\text { Products }\end{array}$ & $\begin{array}{l}\text { Sanitary Napkin, Diapers, Cloth, } \\
\text { Soap and water only }\end{array}$ \\
\hline & $\begin{array}{l}\text { Less frequent } \\
\text { time in washing } \\
\text { hands }\end{array}$ & After coughing and sneezing \\
\hline & $\begin{array}{l}\text { Used in } \\
\text { washing hands }\end{array}$ & $\begin{array}{l}\text { Bath soap, laundry bar soap, } \\
\text { alcohol, bleaching soap, water } \\
\text { only }\end{array}$ \\
\hline & $\begin{array}{l}\text { Identified } \\
\text { Hygiene related }\end{array}$ & Importance of Personal Hygiene \\
\hline & $\begin{array}{l}\text { topics they wish } \\
\text { to learn }\end{array}$ & $\begin{array}{l}\text { Importance of Proper Solid Waste } \\
\text { Disposal }\end{array}$ \\
\hline & more about & Importance of Material Recycling \\
\hline & & How to Keep Water Safe \\
\hline & & Feminine Hygiene Care \\
\hline & & $\begin{array}{l}\text { Diseases caused by poor WASH? } \\
\text { practices }\end{array}$ \\
\hline
\end{tabular}

On Recycling and Solid Waste Management, it was revealed that the indigenous peoples have low to no knowledge on recycling materials, thus, they do not practice it. However, as pointed out by Oyegunle and Thompson (2018), most of the materials that indigenous people own are being utilized to the point of becoming too worn out and can no longer be used for other purposes. In contradiction to this, Allende-Hernández and Salinas (2017) had a suggestion of giving trainings to the
IP community on how to recycle materials they thought they can no longer use to discourage the unhealthy practices of burning or burying non-recyclable items.

On Hygienic Practices, specifically with regard to their food consumption, indigenous peoples in the locality prefer to cook their own meal and once they buy from other vendors, they observe cleanliness on the food cooking and preparation. In dealing with diarrheal infections, they opt first to use herbal medicines, before they submit themselves or other family members to barangay centers. Women IP members already adapted the use of sanitary napkin during menstrual period and diapers for heavy flow, while others still opt to use the traditional cloth or soap and water only. When asked about the times they wash their hands, it was only on the item 'after coughing and sneezing' they did not nod for affirmation. On the materials they use in washing hands, it was evident that they already know the proper ways on how to do it, which crashed out this item on their identified hygiene related topics they wish to know more about. These improved knowledge, attitude and practices of the indigenous peoples on their hygiene were influenced by their non-IP counterparts in the local community. This goes with the contention of Malata-Silva (2017) when she claimed that IP members who live with non-IPs in any community were evidently influenced on their way of life, especially on health care and overall lifestyle.

\section{CONCLUSION}

With the statements collected from the participants, evidences support that promoting Health Science Education (HSE) is vital to the target community. Some improved practices are acknowledged and should also be strengthened to avoid any relapse event. It should be inculcated in the operations of these indigenous peoples the right attitude and proper hygienic practices to save themselves from the pressures of submitting themselves to hospitals and escape those unnecessary financial obligations. Thus, with the highlighted needs for each indicator reflected as results on the answered questionnaire, it is suggested that an extension activity should follow this research endeavor, which will focus on information dissemination on HSE and put more efforts on providing the community meaningful inputs that should change their mindset on the importance of being holistically healthy.

\section{ACKNOWLEDGEMENTS}

Without the support of the College President of the Davao del Norte State College, Dr. Joy M. Sorrosa, and the Dean of the Institute of Teacher Education, Dr. Arnold M. Duping, patience, and guidance of Research, Extension and Production (REP) Office, this study would not have been completed. It is to them that the researchers owe the deepest gratitude.

\section{LITERATURE CITED}

[1]. Allende-Hernández, O., \& Salinas, J. (2017). Usages and Customs of the Indigenous Communities in Favour of the Reduction of the 
Digital Divide: A Case Study of the Nuu Savi People. Indigenous People, 1-20.

[2]. Bradford, L. E., Bharadwaj, L. A., Okpalauwaekwe, U., \& Waldner, C. L. (2016). Drinking water quality in Indigenous communities in Canada and health outcomes: a scoping review. International journal of circumpolar health, 75(1), 32336.

[3]. Ghebreyesus, T. A. (2018). Improving the health of Indigenous people globally. The Lancet Oncology, 19(6), e277.

[4]. Hibbard, J. H., \& Greene, J. (2013). What the evidence shows about patient activation: better health outcomes and care experiences; fewer data on costs. Health affairs, 32(2), 207-214.

[5]. Malata-Silva, J. H. (2017). Community Organizing Participatory Action Research (COPAR) in curriculum development. ASEAN Journal of Community Engagement, 1(1), 3 .

[6]. Oyegunle, A., \& Thompson, S. (2018). Wasting Indigenous Communities: A Case Study with Garden Hill and Wasagamack
First Nations in Northern Manitoba, Canada. The Journal of Solid Waste Technology and Management, 44(3), 232-247.

[7]. Sarfati, D., Robson, B., Garvey, G., Goza, T., Foliaki, S., Millar, E., \& Scott, N. (2018). Improving the health of Indigenous people globally. The Lancet Oncology, 19(6), e276.

[8]. Smith, L. T. (2013). Decolonizing methodologies: Research and indigenous peoples. Zed Books Ltd.

[9]. Smylie, J., \& Firestone, M. (2016). The health of indigenous peoples. D. Raphael (3rd ed.) Social determinants of health: Canadian perspective, 434-469 